\title{
Documenta
}

\section{Um Otelo brasileiro: violência e metateatralidade em Iago}

Marcus Mota 


\title{
Um Otelo brasileiro: \\ violência e metateatralidade em Iago'
}

\author{
marcus Mota \\ Universidade de Brasília - Brasil \\ marcusmota@unb.br
}

Resumo: Este texto procura apresentar os pressupostos para a elaboração da peça Iago. Escrita a partir de Otelo, Iago busca colocar em primeiro plano algo presente no texto shakesperiano: o espetáculo cruento em torno da morte de uma mulher inocente.

Palavras-chave: Shakespeare, Otelo, Violência, Metateatralidade.

Abstract: This paper deals with how Iago was elaborated as a rereading of Shakespeare's Othello. The main focus of Iago was display a theatrical exploration of death and violence against an innocent woman.

Keywords: Shakespeare, Othello, Violence, Metatheatre.

Empresto o título desta minha conferência do importante livro de Helen Caldwell sobre a narrativa de Machado de Assis². A exegese que Caldwell realiza de Dom Casmurro demonstra como a obra shakesperiana é reinterpretada, com conseqüente ampliação de suas situações e personagens.

Mais que uma adaptação ou transposição do material shakesperiano, Machado de Assis proporciona rediscussão de linhas hegemônicas de Otelo, desestabilizando certezas que a obra teatral procura desenvolver na busca da intensidade dos efeitos de representação.

Se em Otelo há um esforço em mostrar como as pessoas se enganam sobre a realidade, Machado de Assis situa esse engano não em um agente externo, mas em uma deliberada ação por parte da personagem. Em Dom Casmurro, o jogo de disfarces e mal-entendidos não se situa entre as personagens, mas é proposto por um narrador claudicante, que se denuncia em sua obsessão em comprovar que aquilo que afirma é o que aconteceu³.

Em todo caso, tanto o texto teatral shakesperiano quanto a narrativa machadiana projetam um tipo de envolvimento com sua recepção através da assimetria entre as personagens. O drama não está no pathos do ciúme, mas no saber (ou no não saber)4 ${ }^{4}$.

1 Texto apresentado ao International Shakespeare Assoociation World Congress. Brisbane, 2006. Agradecimentos à FINATEC, por despesas de viagem e hospedagem.

2 CALDWELL 2002.

3 SOUZA 2006.

4 MOTA 1998. 
A díade Iago-Otelo provoca tal assimetria. Em Otelo, Shakespeare trabalha em uma estrutura cômica, tipo personagem escada, embaralhando o primeiro e segundo planos 5 . A audiência acompanha arco ascendente do oficial rebaixado Iago em sua vingança contra seu senhor Otelo. Otelo, até a revelação final, de nada sabe. E assassina injustamente sua esposa, deixando-se levar pelas palavras e fatos fabricados por Iago.

Em Dom Casmurro, a díade é incorporada por personagens que se desdobram em Iago-Otelo. A dualidade cômica de Otelo é um horizonte de ação, um padrão de personagens cindidos. A ênfase na subjetividade, em centros subjetivos acarreta personalidades plásticas, divididas.

Ou seja, para as audiências modernas, Machado de Assis mostra como a interiorização de um desdobramento personativo sobrepõe valores antagônicos. Afinal, a aproximação entre Iago e Otelo não é fortuita ou casual. Há um pouco (muito) de Iago em Otelo. E a singularidade da personagem não significa a separação de valores antagônicos.

Diante disso, Machado de Assis efetiva no Brasil, uma ex-colônia européia, uma tradição de apropriação criativa de clássicos. E essa apropriação criativa não só produz um novo ponto de partida, um novo original, como rediscute aspectos fundamentais da obra shakesperiana. Fora das metrópoles, antes que se discutissem questões pós-coloniais, Machado de Assis, no ato de transformar Shakespeare, ilumina procedimentos que possibilitam o entrechoque de culturas e modos de representação. Ao deslocar a questão do engano, de uma didática do mal para uma internalização da consciência das ações e suas conseqüências, Machado de Assis situa o universo imaginativo da díade Otelo-Iago em outros parâmetros que o modelo judaico-cristão. O que interessa agora é a ocasião, a oportunidade, a deliberada atitude de fazer valer a sua disposição. Fora do reino da causalidade teológica, baseada em pecado-punição, ninguém morre ou mata em Dom Casmurro. O efeito é maior que a causa. E não se luta por princípios, mas por uma satisfação pessoal.

Com esse precedente, dispus-me a também me apropriar criativamente da obra shakesperiana, elaborando o texto do espetáculo Iago. A possibilidade de se transformar os clássicos a partir de sua reinterpretação constitui um trabalho cotidiano no teatro. Sempre estamos modificando seja em função das circunstâncias, seja em função de um processo criativo específico.

A minha versão teatral de Otelo foi motivada por minha indignação ao ler a provocativa análise que H. Bloom realiza da obra Shakesperiana. Rompendo com as expectativas de leituras, Bloom nos oferece um panegírico de Iago: Iago é "um artista tão livre de si mesmo (...) Grande improvisador, ele age com vigor e senso de oportunidade, ajustando sua trama às ocasiões que se apresentam.(...) É um inventor, um indivíduo propenso a experimentos, sempre disposto a testar mecanismos até então desconhecidos.(... $)^{\text {"” }}$

5 HELIODORA 1998.

6 BLOOM 1989:539. 
Tal elogio chega aos extremos quando Bloom afirma que "Shakespeare inventa em Iago um sublime poeta cômico, de natureza sádica, um arconte do niilismo que sente prazer em devolver às trevas o deus da guerra. Será possível inventar lago sem que tal feito traga ao inventor grande satisfação? Será que não apreciamos Iago, apesar da ambivalência de nossos sentimentos por ele ? ?"

Essa perigosa equação entre teatralidade e excelência, que Bloom aplica a Iago, foi realmente determinante para que eu revisitasse o texto shakeaperiano em busca de respostas. Pois a sublimidade de Iago, ao mesmo tempo em que iguala teatralidade e sofismática e sofisticada argumentação, também aponta para um fatal esquecimento: o assassinato de uma mulher, e de uma mulher inocente.

Tal fato não pode passar desapercebido quando se encena Shakespeare no Brasil. Machado de Assis já havia cifrado este esquecimento ao propor uma ambivalente figura feminina em seu Dom Camurro. Grande parte da discussão após o romance resumia-se ao adultério ou não de Capitu. Em uma cultura marcada por restrições e violência contra a mulher, as figuras shakesperianas necessitam de uma nova utilização. Nos trópicos, a erotização do feminino e não sua idealização é o que predomina. Esta erotização limita a mulher à esfera da sexualidade (luxúria ou reprodução). O suposto adultério de Capitu demarca o enquadramento que Bentinho tem de uma mulher que escapa à lógica hegemônica. A negativização da mulher é uma contrapartida da descontinuidade entre representação e realidade. Ironicamente, Machado de Assis desconstrói o relato de Bentinho a partir do próprio relato. Bentinho fala contra si mesmo.

De forma que o desmesurado elogio de Iago não só é um louvor de certas habilidades da personagem como também uma argumentação que busca definir a teatralidade do espetáculo shakesperiano. A sedução que Otelo provoca nos espectadores estaria relacionada com a inteligência e argúcia do personagem Iago. Mas e o último e sanguinário ato? E a bofetada de Otelo em Desdêmona no quarto ato?

Contrariamente a essa intelectualização das relações entre os personagens, a teatralidade de Otelo fundamenta-se em um elaborado e detalhado espetáculo violento, cujo desenlace vai sendo realizado pouco a pouco, com pequenas, intensas e exatas doses de agressividade. As coisas não se resolvem na mente, em um plano superior sublimado, mas em uma arena terrível, feroz. A transformação de Otelo em assassino conduz a platéia para o desejo de ver consumado os atos que são mostrados ou parcialmente sugeridos. Quando, enfim, palavra e ação se integram, Desdêmona é morta.

Por mais que o espetáculo, ao explicitar tamanha progressão da violência, também explicite a manipulação de Iago, é o assassinato, é a longa cena de mortal clímax o que captura toda a atenção. Em cena o contraste entre a brutalidade primitiva de Otelo e a fragilidade semi-virginal de Desdêmona intensifica os atos de ataque, de aniquilação. A desproporção entre as figuras projeta um desejo de posse e destruição, invertendo os

7 BLOOOM 1989:559. 
papéis entre vítima e perpetrador da desgraça. É como se Desdêmona provocasse sua própria morte por ser o que é.

Objetivando reverter e denunciar tanto o intelectualismo de H.Bloom quanto a atração que o espetáculo sangrento causa, estruturei Iago em um metadrama: atores que acabam de interpretar a peça Otelo se vêem tomados por seus papéis e passam a agir em suas vidas como os personagens da peça.

Para fazer isso, selecionei cenas, personagens e frases emblemáticas da peça de Shakespeare. Iago começa com a cena final de Otelo: Otelo, após ter assassinado sua esposa, é preso, discute com Iago - que nada responde - e depois se suicida. O nível formal do verso shakesperiano é mantido, ocasionando um reconhecimento de que há uma peça dentro da peça que estamos assistindo.

Porém, no mesmo texto há a inserção de palavras outras - exclamações, xingamentos, adjetivações - que vão causando um estranhamento, uma passagem do universo conhecido da peça para o universo que será posteriormente representado.

Ainda nessa abertura, outra interferência: o deslocamento da canção que Desdêmona canta no quarto ato após ter sido esbofeteada. A cena de abertura é, pois, um funeral para os mortos, uma lamentação. Deslocando o lamento para antes dos fatos, subverte-se a lógica de se compadecer apenas após os acontecimentos. Iago não é uma celebração das habilidades manipuladores de Iago, mas um lamento-denúncia sobre as conseqüências dessa manipulação.

Ampliando a metateatralidade, a peça após a abertura se articula em dois planos: o plano da guerra e todos seus atos correlacionados - maus tratos físicos, tortura, abuso, estupro e morte - interpretado por um coro e o plano da peça, com atores entregues à possessão de seus papéis. Em alguns momentos estes planos se interpenetram. Em outros, temos espetáculos paralelos. Mas sempre uma perspectiva não unificada.

Ou seja, essa articulação de planos duplica o jogo de interpretação da peça, na qual temos atores de hoje sendo possuídos pelos papéis da peça Otelo. Dentro desse desdobramento generalizado, tudo o que se mostra apresenta-se como feito, organizado para produzir efeitos. O espetáculo se mostra como espetáculo e se denuncia como espetáculo. A maquinaria de destruição, o ritmo persecutório que vai tomando conta da cena, com a transformação de Otelo em assassino não é o eixo principal do espetáculo. Há múltiplos focos, uma dispersão organizada de interesses. Cada personagem procura justificar-se e expor sua hesitação frente a essa fusão entre ator e papel. Os personagens hesitantes e desdobrados questionam o que devem fazer como personagens desse espetáculo violento. $\mathrm{E}$ a maior violência não é a da morte de Desdêmona e sim a da desconstrução do espetáculo com celebração da violência.

A última cena de Iago é um anticlímax. Toda ela é construída a partir do texto shakesperiano submetido a dois procedimentos de deformação: as falas dos personagens são atribuídas a outros atores e são traduzidas por um vocabulário mais agressivo e de baixo calão. Ao fim, o ator que interpreta Cássio, após ter sido barbaramente violentado e viola- 
do, é morto pelo ator que interpreta Otelo, tudo sob o comando do ator que faz o papel de Iago dizendo as falas de Desdêmona. Otelo não mata Desdêmona. Em um final bizarro, ele mata e estupra um homem, um seu igual. O grotesco de tudo isso procura mostrar a cegueira dos atos de Otelo e da platéia. O ator que interpreta Iago vira-se para o público e solicita que novos crimes sejam efetivados. Se as pessoas aplaudem vergonhosas mortes como esta, por que se envergonhariam de em suas vidas agirem como em parte agiram os personagens da peça?

Do mundo fechado ao universo infinito - em uma cultura carnavalizada como a do Brasil, espetáculos que encerrem a violência por ela mesma concorrem com a explosão de agressividade dos grandes centros urbanos e com formas de espetáculos massivos (filmes, tv) que exploram negativamente expectativas e eventos funestos. A peça Otelo no Brasil é uma oportunidade para que a fusão entre cultura da violência e sociedade como espetáculo se defrontem com a ilusão de suas práticas e ideais e percebam que

1 - ninguém quer ser vitimizado;

2 - as coisas não acontecem só com os outros;

3 - eu sou capaz de matar.

\section{Referências Bibiográficas}

BLOOM,H. Shakeaspeare. A Invenção do Humano. São Paulo: Objetiva,1998.

CALDWELL, H. O Otelo Brasiliero de Machado de Assis (The Brazilian Othello of Machado of Assis). Ateliê Editorial,2002.

HELIODORA, B. Falando de Shakeapeare ( Talking about Shakespeare) Perspectiva, 1998.

MOTA, M. "Fundamentos para uma tradição compreensiva da realidade:Machado de Assis e o instinto de nacionalidade" In: ABRALIC, 1990, UFMG. Anais do 2o. Congresso ABRALIC. Belo Horizonte : Editora UFMG, 1990. v. 1. p. 111-117.

MOTA, M. Imaginação dramática. Texto\&Imagem, 1998.

SOUZA, R. M. O Romance Tragicômico de Machado de Assis. Rio de Janeiro: Editora Uerj, 2006. 